\title{
Review
}

Drug/Regimen

Diabetes Metab J 2021;45:326-336

https://doi.org/10.4093/dmj.2020.0272

pISSN 2233-6079 · eISSN 2233-6087

DIABET\&S \& METABOLISM JOURNAL

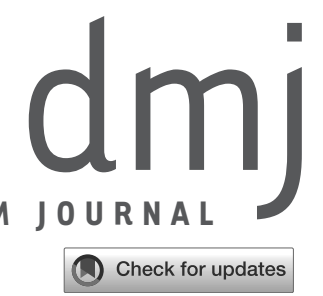

\section{Lobeglitazone: A Novel Thiazolidinedione for the Management of Type 2 Diabetes Mellitus}

\author{
Jaehyun Bae ${ }^{1, \star}$, Taegyun Park ${ }^{2, *}$, Hyeyoung Kim ${ }^{3}$, Minyoung Lee ${ }^{4}$, Bong-Soo Cha ${ }^{4}$ \\ ${ }^{1}$ Division of Endocrinology and Metabolism, Department of Internal Medicine, International St. Mary's Hospital, Catholic Kwandong University College of \\ Medicine, Incheon, \\ ${ }^{2}$ Department of Clinical Research Design and Evaluation, Samsung Advanced Institute for Health Sciences \& Technology, Sungkyunkwan University, Seoul, \\ ${ }^{3}$ Medical information and Pharmacovigilance Team, CKD Pharmaceutical Corp., Seoul, \\ ${ }^{4}$ Division of Endocrinology and Metabolism, Department of Internal Medicine, Yonsei University College of Medicine, Seoul, Korea
}

Type 2 diabetes mellitus (T2DM) is characterized by insulin resistance and $\beta$-cell dysfunction. Among available oral antidiabetic agents, only the thiazolidinediones (TZDs) primarily target insulin resistance. TZDs improve insulin sensitivity by activating peroxisome proliferator-activated receptor $\gamma$. Rosiglitazone and pioglitazone have been used widely for T2DM treatment due to their potent glycemic efficacy and low risk of hypoglycemia. However, their use has decreased because of side effects and safety issues, such as cardiovascular concerns and bladder cancer. Lobeglitazone (Chong Kun Dang Pharmaceutical Corporation), a novel TZD, was developed to meet the demands for an effective and safe TZD. Lobeglitazone shows similar glycemic efficacy to pioglitazone, with a lower effective dose, and favorable safety results. It also showed pleiotropic effects in preclinical and clinical studies. In this article, we summarize the pharmacologic, pharmacokinetic, and clinical characteristics of lobeglitazone.

Keywords: Diabetes mellitus, type 2; Lobeglitazone; Thiazolidinediones

\section{INTRODUCTION}

Type 2 diabetes mellitus (T2DM) is a chronic progressive metabolic disease characterized by insulin resistance and $\beta$-cell dysfunction [1]. Because the pathophysiology of T2DM is complex and multifactorial, a variety of oral antidiabetic agents (OADs) have been developed based on the underlying mechanisms associated with T2DM. Among the OADs developed so far, the thiazolidinedione (TZD) class is one of the classes of OADs which primarily targets insulin resistance [2].

TZDs improve insulin sensitivity by activating peroxisome proliferator-activated receptor $\gamma(\operatorname{PPAR} \gamma)$ [3] and were introduced as an OAD class in the late 1990s. The first TZD approved for T2DM treatment was troglitazone, which was withdrawn from the market in 2000 because of hepatotoxicity [4]. Other TZDs, rosiglitazone and pioglitazone, were approved by the U.S. Food and Drug Administration in 1999 and have been used widely for T2DM treatment due to their potent glycemic efficacy and low risk of hypoglycemia. They have also shown excellent glycemic durability $[5,6]$. However, because of side effects and safety issues, such as cardiovascular concerns [7] and bladder cancer [8], the use of rosiglitazone and pioglitazone has been restricted or decreased significantly during the 2010s.

Lobeglitazone (Chong Kun Dang Pharmaceutical Corporation, Seoul, Korea) is a novel TZD, developed to meet the demands for an effective and safe TZD. Its development program was initiated in May 2000 by Chong Kun Dang Pharmaceutical Corporation and it was approved for the management of T2DM in Korea in July 2013.

Although there is still a need for further studies, lobeglitazone has shown good results in terms of efficacy and safety
Corresponding author: Bong-Soo Cha (D) https://orcid.org/0000-0003-0542-2854 Division of Endocrinology and Metabolism, Department of Internal Medicine, Yonsei University College of Medicine, 50 Yonsei-ro, Seodaemun-gu, Seoul 03722, Korea E-mail: BSCHA@yuhs.ac

${ }^{\star}$ Jaehyun Bae and Taegyun Park contributed equally to this study as first authors.

Received: Nov. 16, 2020; Accepted: Feb. 23, 2021
This is an Open Access article distributed under the terms of the Creative Commons Attribution Non-Commercial License (https://creativecommons.org/licenses/by-nc/4.0/) which permits unrestricted non-commercial use, distribution, and reproduction in any medium, provided the original work is properly cited. 
in studies performed to date. In this article, we will review the pharmacologic, pharmacokinetic, and clinical characteristics of lobeglitazone.

\section{LOBEGLITAZONE CHARACTERISTICS}

\section{Chemistry}

Lobeglitazone is a pharmacophore which has a 2,4-thiazolidinedione group with an ethoxy-benzyl N-methylamino group bound to this as a connecting link. Its structural formula is $\mathrm{C} 24 \mathrm{H} 24 \mathrm{~N} 4 \mathrm{O} 5 \mathrm{~S}$, and the chemical name is 5-[4-(2-\{[6-(4-Methoxy-phenoxy)-pyrimidin-4-yl]-methyl-amino\}-ethoxy)benzyl]-thiazolidine-2,4-dione hydrosulphuric acid. The cocrystal structure of lobeglitazone with PPAR $\gamma$ is shown in Supplementary Fig. 1.

Lobeglitazone was based on modification of the rosiglitazone structure to introduce a p-methoxyphenoxy group at the 4-position of the pyrimidine moiety [9]. This contributes to enhanced binding affinity of lobeglitazone for PPAR $\gamma$, with docking analysis suggesting that the binding affinity of lobeglitazone is 12 times higher than that of rosiglitazone and pioglitazone [9]. The p-methoxyphenoxy group enables extended interaction with the hydrophobic pocket, and this could also affect the cyclin dependent kinase 5-mediated phosphorylation of PPAR $\gamma$ at Ser245, which changes the expression of genes such as adiponectin and adipsin that are associated with insulin sensitivity without general transcriptional activity of $\operatorname{PPAR} \gamma[10]$.

\section{Metabolic effects: preclinical studies}

The effect of lobeglitazone on PPAR $\gamma$ activity was assessed by time-resolved fluorescence resonance energy transfer (TRFRET) assay. The half maximal effective concentration $\left(\mathrm{EC}_{50}\right)$ of lobeglitazone for PPAR $\gamma$ was $0.1374 \mu \mathrm{M}$, and it showed selectivity for PPAR $\gamma\left(\mathrm{PPAR} \alpha / \mathrm{PPAR} \gamma \mathrm{EC}_{50}\right.$ ratio=3,976) [11]. The $\mathrm{EC}_{50}$ values of rosiglitazone and pioglitazone for PPAR $\gamma$ were 0.1076 and $0.5492 \mu \mathrm{M}$, respectively.

In in vivo studies, lobeglitazone showed a significant glucose-lowering effect in Zucker diabetic fatty (ZDF) rats, $d b / d b$ and KK/Upi-Ay/J (KKAy) mice. Lobeglitazone acted in a dosedependent manner and was most effective at $0.3 \mathrm{mg} / \mathrm{kg}$, at which dose it was equivalent to $30 \mathrm{mg} / \mathrm{kg}$ of pioglitazone [11]. Lobeglitazone increased glucose uptake in 3T3-L1 adipocytes and L6 muscle cells, with the effects greater than those observed with pioglitazone [11], and showed beneficial effects on pancreatic $\beta$-cell survival in $d b / d b$ mice $[12,13]$. It was also found to inhibit protein tyrosine phosphatase $1 \mathrm{~B}$ in vitro; this enzyme is involved in the regulation of insulin and leptin signaling and is implicated in the development of insulin resistance and T2DM [14].

Other metabolic effects of lobeglitazone have also been evaluated. The effect of lobeglitazone on lipid profiles was compared to that of pioglitazone in ZDF rats, with plasma triglyceride (TG) and free fatty acid (FFA) levels reduced similarly in both treatment groups (TG reduced by $77 \%$ with lobeglitazone $10 \mathrm{mg} / \mathrm{kg}$ and $75 \%$ with pioglitazone 10 or $30 \mathrm{mg} / \mathrm{kg}$; FFA reduced by $98 \%$ with lobeglitazone $10 \mathrm{mg} / \mathrm{kg}$ and $97 \%$ with pioglitazone 10 or $30 \mathrm{mg} / \mathrm{kg}$ ) [11]. Lobeglitazone enhanced lipid accumulation and, adipocyte differentiation through increasing the expression of genes regulated by PPAR $\gamma$ such as adipocyte proterin 2 (aP2), and CD36 to a greater extent than seen with other TZDs in vitro [11]. Long-term administration of lobeglitazone had a beneficial role on adipose tissue remodeling, by inducing differentiation of preadipocytes into insulinsensitive small adipocytes, and redistribution from visceral to subcutaneous adipose depots, and induced the differentiation of white adipocytes to beige adipocytes and was associated with the development of brown adipocytes [13]. Lobeglitazone also enhanced beige adipocyte formation and thermogenic gene expression in lean mice after cold exposure, to a greater extent than observed with pioglitazone or rosiglitazone [15].

\section{Potential pleiotropic effects: preclinical studies}

Similar to the therapeutic effect of pioglitazone on fatty liver, lobeglitazone also attenuated hepatic steatosis in obese mice by increasing insulin sensitivity and inhibiting hepatic lipogenesis $[16,17]$.

A few studies have reported favorable effects of lobeglitazone on atherosclerosis in in vitro or in vivo models $[18,19]$. Lobeglitazone significantly reduced neointimal formation after balloon injury in rat carotid arteries and reduced the atheromatous burden in the aorta of $\mathrm{ApoE}^{-/-}$mice fed with a high-fat/ high-cholesterol diet [18]. These results were in line with previous studies showing that PPAR $\gamma$ activation inhibits vascular smooth muscle cell proliferation and inflammatory pathways and, therefore, TZDs might be expected to protect or relieve the endothelium from atherosclerosis [20,21]. Lobeglitazone also inhibited the formation of lipid droplets in foam cells in an in vitro model [22].

Anti-inflammatory characteristics of lobeglitazone were evi- 
dent in a murine model of asthma [23], and lobeglitazone improved renal fibrosis in mice by inhibiting transforming growth factor- $\beta /$ Smad signaling [24].

These preclinical studies suggest that lobeglitazone might have beneficial effects on various organs; however, clinical studies are needed to evaluate the potential role of lobeglitazone in these settings.

Other studies evaluated potential safety concerns with TZDs, including bone health and cancer risk. Both adipocytes and osteoblasts differentiate from mesenchymal stem cells, a process that is in part regulated by PPAR $\gamma$ [25]. Consequently, there is a concern that long-term administration of TZDs could have adverse effects on bone, as was seen with rosiglitazone which reduced bone mineral density (BMD) [26,27]. Studies with lobeglitazone found that it did not inhibit osteoblast differentiation in vitro and had no adverse effect on BMD in mice [25].

Finally, there is evidence that some PPAR agonists, such as pioglitazone, may increase the risk of bladder cancer [28,29]. Long-term studies in rats and mice suggested that lobeglitazone had a low carcinogenic potential and did not induce urothelial tumors [30,31].

\section{Pharmacokinetics}

Data on the pharmacokinetics of lobeglitazone have been obtained from healthy volunteers and patients with renal impairment.

\section{Healthy adults}

After single oral doses of lobeglitazone in healthy male subjects, peak plasma levels of lobeglitazone were reached at 1 to 3 hours and then declined monoexponentially with a half-life of 7.8 to 9.8 hours [32]. In males, peak plasma concentration $\left(\mathrm{C}_{\max }\right)$ and area under the plasma concentration-time curve from time 0 to infinity ( $\mathrm{AUC}_{\text {inf }}$ ) increased in a dose-proportional manner across the dose range of 1 to $4 \mathrm{mg}$ [32]. After multiple-dose administration (once-daily regimen) in healthy males, lobeglitazone reached steady-state concentrations by day 5 , and no clinically significant drug accumulation was observed [32].

When a single doses of lobeglitazone was administered to healthy female subjects, systemic lobeglitazone exposure after $2 \mathrm{mg}$ was similar to that seen in males, but after administration of $4 \mathrm{mg}$, exposure was 2.36 -fold greater in females than in males [33]. However, dose adjustment based on sex alone is not necessary because the approved dose for clinical use is lower
Table 1. Summary of lobeglitazone pharmacokinetic parameters after a single oral dose of $0.5 \mathrm{mg}$ in health male subjects $[11,32]$

\begin{tabular}{lc}
\hline Parameter & Value \\
\hline $\mathrm{T}_{\max }, \mathrm{hr}^{\mathrm{a}}$ & $1.00 \pm 0.50$ \\
$\mathrm{C}_{\max }, \mu \mathrm{g} / \mathrm{L}$ & $50.0 \pm 7.9$ \\
$\mathrm{AUC}_{\text {inf }}, \mu \mathrm{g} / \mathrm{hr} / \mathrm{L}$ & $379.0 \pm 44.6$ \\
$\mathrm{CL} / \mathrm{F}, \mathrm{L} / \mathrm{hr}$ & $1.33 \pm 0.15$ \\
$\mathrm{t}_{1 / 2}, \mathrm{hr}$ & $7.82 \pm 0.43$ \\
$\mathrm{f}_{\mathrm{e}}, \%$ & Negligible \\
Protein binding, \% & $99.3-99.9$ \\
Metabolism & $\mathrm{CYP} 3 \mathrm{~A} 4$ (main), 2C19 and 2D6 \\
Metabolites & M7 (O-demethylation; main), \\
& M9 (N-demethylation) \\
\hline
\end{tabular}

Values are presented as mean \pm standard deviation unless indicated otherwise.

$\mathrm{T}_{\max }$, time to $\mathrm{C}_{\max } ; \mathrm{C}_{\max }$, maximum plasma concentration; $\mathrm{AUC}_{\mathrm{inf}}$, area under concentration-time curve from 0 to infinity; CL/F, oral clearance; $t_{1 / 2}$, elimination half-life; $f_{e}$, fraction excreted unchanged in urine; $\mathrm{CYP}$, cytochrome $\mathrm{P} 450$.

${ }^{a}$ Median and range are presented for $\mathrm{T}_{\max },{ }^{b}$ Fraction of lobeglitazone excreted unchanged in urine was below the lower limit of quantification $(0.2 \mathrm{ng} / \mathrm{mL})$.

(0.5 mg/day). Pharmacokinetic parameters after a single dose of lobeglitazone $0.5 \mathrm{mg}$ in males are summarized in Table 1.

Lobeglitazone clearance was mainly mediated by liver metabolism and the ratio of renal excretion was predicted to be $<1.0 \%$ [32]. Based on an in vitro human liver microsomal study, the main cytochrome P450 (CYP) isoforms involved in the hepatic metabolism of lobeglitazone were cytochrome P450 3A4 (CYP3A4), 2C19, and 2D6 [11].

\section{Food interaction}

In a study that evaluated the effect of food on the pharmacokinetics of a single dose of lobeglitazone $1 \mathrm{mg}$, a slight increase in the AUC for lobeglitazone was observed in subjects who were receiving a high lipid diet compared with fasting subjects [11]. There were no significant between-group differences in the $\mathrm{C}_{\max }$ of lobeglitazone or its active metabolite $\mathrm{M} 7$, and the slight increase in bioavailability with a high lipid diet was not considered to be clinically significant.

In a study evaluating a fixed-dose combination tablet containing lobeglitazone $0.5 \mathrm{mg}$ plus metformin extended-release 1,000 mg, lobeglitazone $\mathrm{C}_{\max }$ decreased by approximately $32 \%$ when administered after a high-fat meal compared with the 
Table 2. Pharmacokinetic profiles in subjects with end-stage renal disease [11]

\begin{tabular}{lcccc}
\hline Parameter & ESRD & Normal & Geometric mean ratio & $90 \%$ CI \\
\hline $\mathrm{C}_{\max }, \mathrm{ng} / \mathrm{mL}$ & $45.56 \pm 10.815$ & $46.43 \pm 7.157$ & 0.9883 & $0.8441-1.1572$ \\
$\mathrm{AUC}_{48}, \mathrm{ng} / \mathrm{hr} / \mathrm{mL}$ & $669.29 \pm 266.348$ & $750.19 \pm 206.071$ & 0.8683 & $0.6319-1.1931$ \\
$\mathrm{AUC}_{\text {inf }}, \mathrm{ng} / \mathrm{hr} / \mathrm{mL}$ & $803.27 \pm 366.626$ & $964.57 \pm 313.819$ & 0.8039 & $0.5507-1.1737$ \\
\hline
\end{tabular}

Values are presented as mean \pm standard deviation.

ESRD, end-stage renal disease; $\mathrm{CI}$, confidence interval; $\mathrm{C}_{\max }$, maximum plasma concentration; $\mathrm{AUC}_{48}$, area under concentration-time curve from 0 to 48 hours; $\mathrm{AUC}_{\mathrm{inf}}$, area under concentration-time curve from 0 to infinity.

fasting state; however, there was no significant difference between the fed and fasted states with respect to lobeglitazone AUC up to the last sampling time [34].

\section{Patients with renal impairment}

An open-label, parallel-group, single-dose, non-randomized study was conducted to evaluate the pharmacokinetic profile of lobeglitazone in patients with renal impairment [11]. The geometric means for $\mathrm{C}_{\max }$ and $\mathrm{AUC}$ in patients with end-stage renal disease (ESRD) were similar to those for subjects with normal renal function (Table 2). $\mathrm{C}_{\max }$ and $\mathrm{AUC}_{\text {inf }}$ values for M7 (the active metabolite of lobeglitazone) were 1.22 and 1.31 times higher in the ESRD group compared with the control group. However, overall, the pharmacokinetic profiles did not differ significantly between the two groups (Table 2).

\section{Drug interactions}

In studies evaluating potential drug-drug interactions in healthy male volunteers, no significant changes were observed in the pharmacokinetics of either drug when lobeglitazone was coadministered with other antidiabetic agents including metformin, glimepiride, dapagliflozin, and sitagliptin [11,35-37]. In general, the $90 \%$ confidence intervals (CIs) for the geometric mean ratios (combination vs. single drug) for $\mathrm{C}_{\max }$ and AUC were within the conventional equivalence range of $80 \%$ to $120 \%$. Exceptions were a slightly increased steady-state $\mathrm{C}_{\max }$ for sitagliptin (ratio, 1.1694; 90\% CI, 1.0740 to 1.27320 ) and a slightly decreased $\mathrm{C}_{\max }$ for glimepiride (ratio, $0.910547 ; 90 \%$ CI, 0.78246 to 1.05960 ), when each was coadministered with lobeglitazone; however, neither of these changes were considered to be clinically significant [11,37].

There were also no significant changes in the pharmacokinetics of either drug when lobeglitazone was coadministered with amlodipine or warfarin $[38,39]$. However, coadministration with ketoconazole, a strong CYP3A4 inhibitor, increased the level of exposure to lobeglitazone by about 33\% (geometric mean ratio for $\mathrm{AUC}_{\mathrm{inf}}, 1.33 ; 90 \% \mathrm{CI}, 1.23$ to 1.44 ) [40].

\section{LOBEGLITAZONE CLINICAL PROFILE}

\section{Glycemic control in type 2 diabetes mellitus Monotherapy}

The short-term glycemic efficacy of lobeglitazone was initially evaluated in a randomized, double-blind, placebo-controlled, phase II study. Patients with T2DM $(n=241)$ received lobeglitazone $0.5 \mathrm{mg}(n=55), 1 \mathrm{mg}(n=54)$, or $2 \mathrm{mg}(n=50)$, or placebo $(n=55)$ for 8 weeks [11]. Changes in fasting plasma glucose levels after 8 weeks of treatment (primary endpoint) were $-20.65 \mathrm{mg} / \mathrm{dL}$ (0.5 mg), $-23.38 \mathrm{mg} / \mathrm{dL}(1 \mathrm{mg}),-33.69 \mathrm{mg} / \mathrm{dL}$ ( $2 \mathrm{mg}$ ), and $-1.8 \mathrm{mg} / \mathrm{dL}$ (placebo). The frequency of edema increased with the higher doses of lobeglitazone, and therefore the minimum effective dose of $0.5 \mathrm{mg}$ once daily was selected as the standard dose for further evaluation.

Subsequently, a phase III study compared the glycemic efficacy of lobeglitazone $0.5 \mathrm{mg}(n=115)$ with placebo $(n=58)$ over 24 weeks [41]. Mean changes in glycosylated hemoglobin (HbA1c) from baseline to week 24 (primary endpoint) were $-0.44 \%$ in the lobeglitazone group versus $0.16 \%$ in the placebo group (mean difference, $-0.6 \% ; P<0.0001$ ). In a 28 -week openlabel extension study, patients who completed the 24-week study either continued on lobeglitazone $(n=65)$ or switched from placebo to lobeglitazone $(n=29)$ [42]. In those patients who received lobeglitazone for 52 weeks, the decrease in HbAlc seen at week 24 was maintained during the extension period; the mean change in $\mathrm{HbAlc}$ from baseline to week 52 was $-0.50 \%$. In patients who switched from placebo to lobeglitazone at week 25, HbAlc improved after administration of lobeglitazone and the mean change in $\mathrm{HbAlc}$ from baseline to week 52 was $-0.52 \%$, similar to that seen in the group who remained on lobeglitazone for the entire 52 weeks. 


\section{Combination therapy}

The antihyperglycemic effect of lobeglitazone in combination with metformin was evaluated in a 24 -week, randomized, double-blind, non-inferiority trial [43]. Patients with T2DM whose blood glucose levels were inadequately controlled (HbA1c 7\% to 10\%) despite a stable dose of metformin $(\geq 1,000 \mathrm{mg} /$ day $)$ were randomized to receive lobeglitazone 0.5 $\mathrm{mg}$ daily $(n=128)$ or pioglitazone $15 \mathrm{mg}$ daily $(n=125)$ as addon therapy to metformin. After 24 weeks of lobeglitazone addon therapy, the mean change in HbAlc (primary endpoint) was $-0.74 \%$, which was almost the same as the change seen in the pioglitazone group (mean difference, $0.01 \%$; $95 \%$ CI, $-0.16 \%$ to $0.18 \%$ ), indicating that lobeglitazone was not inferior to pioglitazone as add-on therapy to metformin with respect to the glucose-lowering effect.

In another randomized controlled study, 24 weeks of treatment with lobeglitazone $(n=121)$ as an add-on to metformin was non-inferior to sitagliptin add-on therapy $(n=126)$ with respect to glycemic efficacy (mean change in $\mathrm{HbAlc}-0.79 \%$ vs. $-0.86 \%$; difference, $0.08 \%$; $95 \%$ CI, $-0.14 \%$ to $0.30 \%$ ) [44].

Apart from metformin, no prospective randomized studies comparing the glycemic efficacy of dual-combination therapy containing lobeglitazone versus other OADs have been published to date. However, a retrospective study assessed the glycemic efficacy of lobeglitazone as monotherapy and in various forms of combination therapy [45]. The study, conducted in a routine clinical practice setting, analyzed 423 patients who took lobeglitazone for more than 180 consecutive days (average age 62.7 years, average duration of T2DM 8.5 years, baseline HbA1c 7.5\%). After a median of 350 days of lobeglitazone treatment, the mean change in $\mathrm{HbAlc}$ was $-0.6 \%$ overall; for lobeglitazone monotherapy it was $-0.34 \%$, for combination therapy with metformin it was $-0.52 \%$, in combination with dipeptidyl peptidase-4 (DPP-4) inhibitors $-0.63 \%$, and in combination with a sulfonylurea $-0.33 \%$. Regarding the triple therapy, the mean change in HbAlc was $-0.84 \%$ for patients taking lobeglitazone, metformin, and DPP- 4 inhibitor, $-0.88 \%$ for those taking lobeglitazone, DPP-4 inhibitor and sulfonylurea, and $-0.33 \%$ for those taking lobeglitazone, metformin, and sulfonylurea. These results suggested that when lobeglitazone is treated in combination with DPP-4 inhibitor, it would improve blood glucose levels more potently than other lobeglitazone-combining regimens.

Recently, a prospective observational study specifically evaluated the effect of initial triple combination therapy including
Table 3. Glycemic efficacy of lobeglitazone in patients with type 2 diabetes mellitus: indirect comparison with pioglitazone based on prospective randomized controlled studies

\begin{tabular}{lccc}
\hline Variable & $\begin{array}{c}\text { Lobeglitazone } \\
(0.5 \mathrm{mg} / \text { day })\end{array}$ & $\begin{array}{c}\text { Pioglitazone } \\
(30 \mathrm{mg} / \text { day })\end{array}$ \\
\hline Monotherapy, short-term [41,47,48] & 24 & 16 & 26 \\
Week & 7.85 & 7.50 & 10.2 \\
Baseline HbA1c, \% & -0.44 & -0.80 & -0.30 \\
Change in HbA1c & $(-0.60)$ & $(-0.60)$ & $(-1.0)$ \\
$\quad$ placebo subtracted), \% & & & \\
Monotherapy, long-term [42,49,50] & 52 & 52 & 52 \\
Week & 7.79 & 8.69 & 8.70 \\
Baseline HbAlc, \% & -0.50 & $-1.41^{\mathrm{a}}$ & $-1.40^{\mathrm{a}}$ \\
Change in HbA1c, \% & & & \\
Add-on to metformin [43,51] & 24 & 24 & 24 \\
Week & 7.93 & 7.96 & 8.40 \\
Baseline HbA1c, \% & -0.74 & $-0.74^{\mathrm{b}}$ & -0.98 \\
Change in HbA1c, \% & & & \\
\hline
\end{tabular}

HbAlc, glycosylated hemoglobin.

aStudy design allowed pioglitazone dose-titration to $45 \mathrm{mg} /$ day, ${ }^{\text {bStudy }}$ used pioglitazone $15 \mathrm{mg} /$ day. All pioglitazone data not marked with superscript ${ }^{\mathrm{a}}$ or ${ }^{\mathrm{b}}$ are from studies which used pioglitazone $30 \mathrm{mg}$ once a day.

lobeglitazone for drug-naïve patients with T2DM with an HbAlc level from $9.0 \%$ to $12.0 \%$ [46]. This study enrolled patients consecutively and used matching based on age and body mass index to select a comparator group who were treated with conventional stepwise dual therapy. After 12 months, HbA1c had decreased by a mean of $4.05 \%$ among recipients of initial triple therapy comprising metformin $1,000 \mathrm{mg} /$ day plus sitagliptin $100 \mathrm{mg}$ /day plus lobeglitazone $0.5 \mathrm{mg}$ /day compared with $3.28 \%$ among recipients of uptitrated treatment with metformin $\geq 1,000 \mathrm{mg} /$ day plus glimepiride $\geq 2 \mathrm{mg} /$ day $(P<0.05)$. Although this study focused on the effectiveness of the initial triple therapy, it also provided evidence for the efficacy and safety of lobeglitazone as a combination therapy for T2DM.

\section{Indirect comparison with pioglitazone}

No randomized studies have directly compared lobeglitazone with pioglitazone as monotherapy. An indirect comparison of the glycemic efficacy of lobeglitazone with pioglitazone based on relevant studies is summarized in Table 3, Fig. 1 [41-43,4751]. Among patients who had a similar level of glycemic control at baseline, lobeglitazone appeared to show similar glu- 

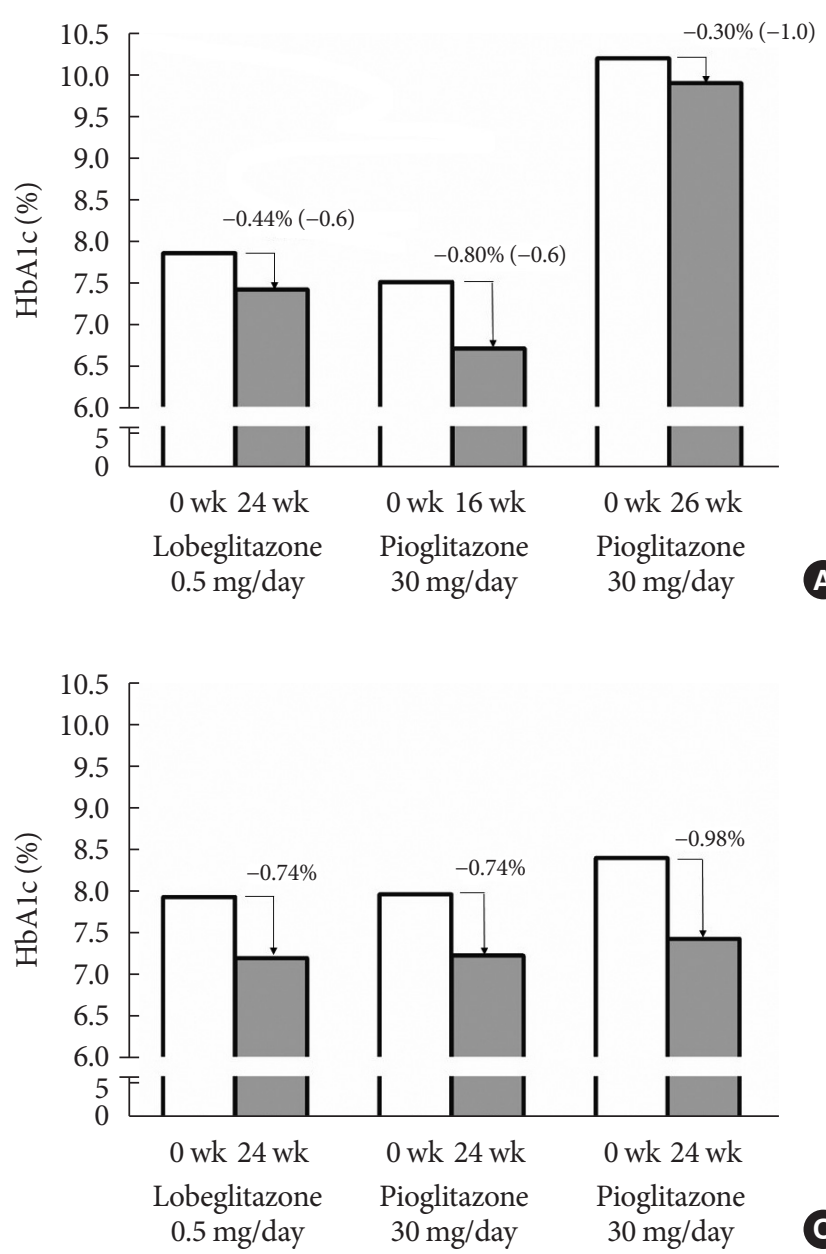

cose-lowering efficacy to pioglitazone. Although the results of some studies seemed to suggest that pioglitazone might have a more potent effect, it should be noted that those studies recruited patients with higher baseline HbAlc.

\section{Potential pleiotropic effects \\ Lipid profiles}

Treatment with lobeglitazone for 24 weeks improved blood levels of TG, high-density lipoprotein cholesterol, and small dense low-density lipoprotein cholesterol (small dense LDLC) [41]. Improvements in TG and small dense LDL-C remained statistically significant during a 28 week-extension period [42]. Similar effects on lipid profiles were seen in the study of lobeglitazone as add-on therapy to metformin [43]. In that study, there were no significant differences in lipid parameters between lobeglitazone and pioglitazone. The effect of lobeglitazone on lipid profiless is summarized in Table 4.

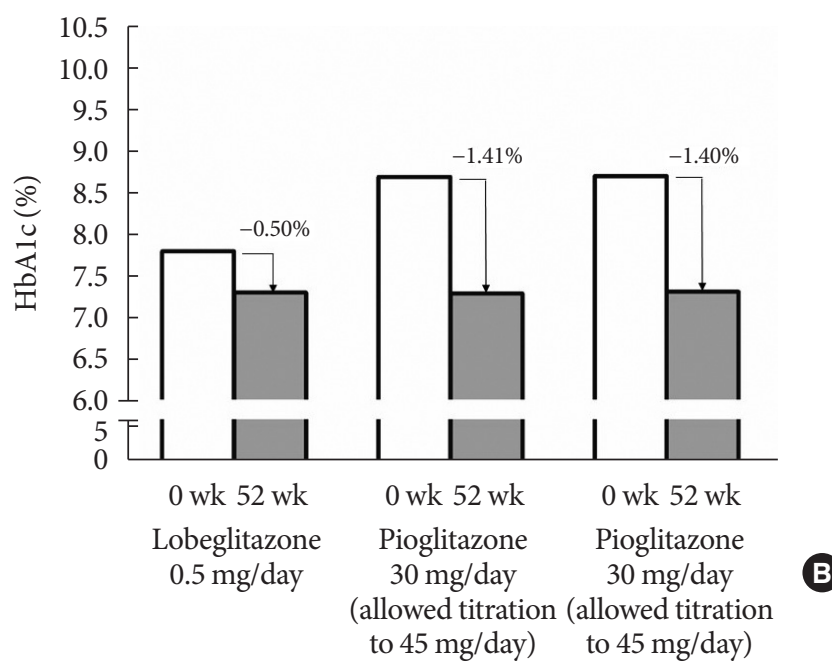

Fig. 1. Indirect comparison of glycemic efficacy between lobeglitazone and pioglitazone in patients with type 2 diabetes mellitus based on previous prospective randomized, controlled studies. (A) Monotherapy, short-term, (B) monotherapy, longterm, and $(\mathrm{C})$ add-on to metformin monotherapy. HbAlc, glycosylated hemoglobin.

\section{Non-alcoholic fatty liver disease}

TZDs are one of the few oral agents recommended as a treatment for non-alcoholic fatty liver disease (NAFLD) [52]. The effects of lobeglitazone on NAFLD were investigated in a single-arm study using transient liver elastography (Fibroscan; Echosens, Paris, France), as well as glycemic, lipid, and liver enzyme profiles [53]. Fifty T2DM patients with NAFLD, defined as controlled attenuation parameter (CAP) $\geq 250 \mathrm{~dB} / \mathrm{m}$, received lobeglitazone $0.5 \mathrm{mg}$ once daily. After 24 weeks, mean CAP significantly decreased (from $313.4 \pm 30.9$ to $297.8 \pm 39.1$ $\mathrm{dB} / \mathrm{m}, P=0.016)$. Liver enzymes including aspartate transaminase, alanine transaminase, and gamma glutamyl transferase also decreased. When patients were grouped as lobeglitazone responders and non-responders in terms of CAP changes, mean changes in HbAlc levels did not differ significantly between the groups, indicating that the therapeutic effect in NAFLD by lobeglitazone was independent of its glycemic efficacy. 
Table 4. Effects on lipid parameters of lobeglitazone as monotherapy or combination therapy

\begin{tabular}{|c|c|c|c|c|c|c|}
\hline Variable & $\begin{array}{c}\text { Total cholesterol, } \\
\mathrm{mg} / \mathrm{dL}\end{array}$ & $\begin{array}{c}\text { LDL-C, } \\
\mathrm{mg} / \mathrm{dL}\end{array}$ & $\begin{array}{c}\text { Small dense LDL, } \\
\%\end{array}$ & $\begin{array}{l}\text { HDL-C, } \\
\mathrm{mg} / \mathrm{dL}\end{array}$ & $\begin{array}{l}\text { Triglyceride, } \\
\text { mg/dL }\end{array}$ & $\begin{array}{c}\text { Free fatty acid, } \\
\qquad \mu \mathrm{Eq} / \mathrm{L}\end{array}$ \\
\hline \multicolumn{7}{|c|}{ Monotherapy [41] } \\
\hline \multicolumn{7}{|c|}{ Lobeglitazone } \\
\hline Baseline & 178.70 & 109.0 & 8.10 & 48.69 & 137.51 & 622.28 \\
\hline Change & 6.0 & 0.95 & $-1.7^{\mathrm{a}, \mathrm{b}}$ & $4.3^{\mathrm{a}, \mathrm{b}}$ & $-19.06^{\mathrm{a}, \mathrm{b}}$ & $-60.39^{\mathrm{a}, \mathrm{b}}$ \\
\hline \multicolumn{7}{|l|}{ Placebo } \\
\hline Baseline & 188.26 & 114.76 & 9.51 & 46.33 & 177.14 & 699.57 \\
\hline Change & 4.84 & -2.64 & 0.62 & 0.76 & 16.14 & -1.0 \\
\hline \multicolumn{7}{|c|}{ Add-on to metformin [43] } \\
\hline \multicolumn{7}{|c|}{ Lobeglitazone } \\
\hline Baseline & 162.03 & 88.55 & 4.02 & 49.50 & 139.95 & 680.0 \\
\hline Change & $6.96^{\mathrm{a}}$ & $4.64^{\mathrm{a}}$ & $-1.23^{\mathrm{a}}$ & $4.64^{\mathrm{a}}$ & $-12.40^{\mathrm{a}}$ & $-100.0^{\mathrm{a}}$ \\
\hline \multicolumn{7}{|c|}{ Pioglitazone } \\
\hline Baseline & 169.76 & 95.13 & 5.07 & 49.11 & 156.78 & 660.0 \\
\hline Change & $7.35^{\mathrm{a}}$ & $4.64^{\mathrm{a}}$ & $-1.06^{\mathrm{a}}$ & $5.80^{\mathrm{a}}$ & $-19.49^{\mathrm{a}}$ & $-90.0^{\mathrm{a}}$ \\
\hline
\end{tabular}

LDL-C, low-density lipoprotein cholesterol; HDL-C, high-density lipoprotein cholesterol.

${ }^{\mathrm{a}} P<0.05$ vs. baseline, ${ }^{\mathrm{b}} P<0.05$ vs. placebo.

\section{Safety and tolerability}

Lobeglitazone was generally well tolerated as monotherapy and in combination with metformin (with or without sitagliptin) $[41-43,46]$. The proportions of adverse events were similar between the lobeglitazone and placebo groups in the placebo-controlled monotherapy trial $[41,42]$ and the lobeglitazone and pioglitazone groups (Table 5) [43] as well as between the lobeglitazone and sitagliptin groups [44] in the active-controlled metformin combination therapy trials.

Peripheral edema, one of the most frequent side effects associated with TZDs, occurred in $3.6 \%$ of patients treated with lobeglitazone monotherapy for 24 weeks [41], and 3.1\% of patients by the end of the monotherapy extension study (total 52 weeks) [42]. No patients had severe edema requiring treatment discontinuation. When lobeglitazone was administered in combination with metformin, $3.9 \%$ of patients experienced edema within 24 weeks, with no cases of severe edema [43]. In another study, peripheral edema and facial edema occurred in $1.67 \%$ and $3.33 \%$ of patients treated with lobeglitazone as addon therapy to metformin [44]. The incidence of peripheral edema seems to be acceptable, considering that the frequency of peripheral edema in clinical studies using pioglitazone monotherapy ranged from $3.6 \%$ to $28.9 \%$ [47-49,54-56].

Weight gain is expected in patients treated with TZDs $[2,57]$.
In the monotherapy trial, the mean bodyweight gain in the lobeglitazone group after 24 weeks was $0.89 \mathrm{~kg}$, whereas in the placebo group bodyweight changed by $-0.63 \mathrm{~kg}$ (mean difference, $1.52 \mathrm{~kg}$; $P<0.0001$ ) [41]. When used as add-on therapy to metformin, mean weight gain was $0.92 \mathrm{~kg}$ in the lobeglitazone group, which did not differ significantly from that of the pioglitazone group (0.76 kg, $P=0.569)$ [43]. Weight gain was greater with lobeglitazone than with sitagliptin when used as add-on therapy to metformin (mean difference, $1.34 \mathrm{~kg}$; $P<0.0001)$ [44].

Hypoglycemia was not reported in the monotherapy trial [41,42], while one subject $(0.8 \%)$ in the lobeglitazone group versus three subjects (2.4\%) in the pioglitazone group reported hypoglycemia when they were used as add-on therapy to metformin [43].

A potential concern with TZDs is an increased risk of bone fractures associated with reduced BMD [2]. The monotherapy trial $[41,42]$ incorporated an evaluation of femur neck and total hip BMD using dual-energy X-ray absorptiometry at week 24 and the week 52, and found no statistically significant difference in change in BMD between lobeglitazone and placebo [58]. Longer-term and mechanistic studies are needed to confirm this finding.

Other potential concerns with some TZDs include heart 
Table 5. Adverse events reported in prospective studies of lobeglitazone

\begin{tabular}{|c|c|c|c|c|c|c|}
\hline \multirow{2}{*}{ Variable } & \multicolumn{2}{|c|}{$\begin{array}{l}\text { Monotherapy } \\
\text { (24 weeks) [41] }\end{array}$} & \multicolumn{2}{|c|}{$\begin{array}{l}\text { Monotherapy-extension } \\
\quad(52 \text { weeks })^{\mathrm{a}}[42]\end{array}$} & \multicolumn{2}{|c|}{$\begin{array}{l}\text { Add-on to metformin } \\
\text { (24 weeks) }[43]\end{array}$} \\
\hline & $\begin{array}{l}\text { Lobeglitazone } \\
\qquad(n=112)\end{array}$ & $\begin{array}{l}\text { Placebo } \\
(n=58)\end{array}$ & $\begin{array}{l}\text { Maintenance } \\
\text { group }(n=64)\end{array}$ & $\begin{array}{l}\text { Switch group } \\
\quad(n=29)\end{array}$ & $\begin{array}{l}\text { Lobeglitazone } \\
\qquad(n=128)\end{array}$ & $\begin{array}{c}\text { Pioglitazone } \\
(n=125)\end{array}$ \\
\hline Any AE & $55(49.1)$ & $30(51.7)$ & $41(64.1)$ & $18(62.1)$ & $66(51.6)$ & $64(51.2)$ \\
\hline Drug-related AE & $10(8.9)$ & $3(5.2)$ & $8(12.5)$ & $2(6.9)$ & $8(6.3)$ & $6(4.8)$ \\
\hline Serious AE & $4(3.6)$ & 0 & $3(4.7)$ & 0 & $7(5.5)$ & $6(4.8)$ \\
\hline \multicolumn{7}{|l|}{ Frequent $\mathrm{AE}$} \\
\hline Hyperglycemia & $3(2.7)$ & $4(6.9)$ & $3(4.7)$ & 0 & $<3 \%{ }^{\mathrm{b}}$ & $<3 \%^{\mathrm{b}}$ \\
\hline Nasopharyngitis & $6(5.4)$ & 0 & $3(4.7)$ & 0 & $6(4.7)$ & $10(8.0)$ \\
\hline URTI & $2(1.7)$ & $3(5.2)$ & $8(12.5)$ & $1(3.5)$ & $2(1.6)$ & $4(3.2)$ \\
\hline Peripheral edema & $4(3.6)$ & 0 & $2(3.1)$ & $0(0)$ & $5(3.9)$ & $2(1.6)$ \\
\hline Headache & $3(2.7)$ & $2(3.5)$ & $3(4.7)$ & $1(3.5)$ & $<3 \%^{\mathrm{b}}$ & $<3 \%^{\mathrm{b}}$ \\
\hline Hematuria & $3(2.7)$ & $3(5.2)$ & $3(4.7)$ & $2(6.9)$ & 0 & 0 \\
\hline \multicolumn{7}{|l|}{ AE of special interest } \\
\hline Hypoglycemia & 0 & 0 & 0 & 0 & $1(0.8)$ & $3(2.4)$ \\
\hline Heart failure & 0 & 0 & 0 & 0 & $<3 \%^{\mathrm{b}}$ & $<3 \%^{\mathrm{b}}$ \\
\hline Ischemic heart disease & 0 & 0 & 0 & 0 & $<3 \%^{\mathrm{b}}$ & $<3 \%^{\mathrm{b}}$ \\
\hline Neoplasm & $1^{\mathrm{c}}(0.9)$ & 0 & $1^{c}(1.6)$ & 0 & 0 & $1^{\mathrm{d}}(0.8)$ \\
\hline
\end{tabular}

Values are presented as number (\%).

$\mathrm{AE}$, adverse event; URTI, upper respiratory tract infection.

${ }^{a}$ Maintenance group received lobeglitazone for weeks 0-52. Switch group received placebo for weeks 0-24 and lobeglitazone for weeks 25-52,

${ }^{b}$ Exact number of cases not presented in the published article, 'Lung cancer, not considered to be related to lobeglitazone by investigators,

${ }^{\mathrm{d}}$ Colon cancer, not considered to be related to pioglitazone by investigators.

failure and bladder cancer [2]. Neither of these were observed in either the lobeglitazone monotherapy or combination therapy trials. Due to the small sample sizes and short study durations, these studies cannot definitively confirm the long-term clinical benefits and risks, and further research is needed to assess cardiovascular outcomes and the risk of bladder cancer with lobeglitazone. However, the risk of bladder cancer with lobeglitazone is considered low based on preclinical studies $[30,31]$ and its negligible urinary excretion $[9,32]$.

\section{Ongoing studies}

Several clinical studies instigated by CKD Pharmaceutical Corp are currently ongoing, and the results are not yet available. These include efficacy and safety trials of lobeglitazone as add-on combination therapy with DPP-4 inhibitors (ClinicalTrial.gov registration number: NCT03641352), sodium glucose cotransporter-2 (SGLT-2) inhibitors (ClinicalTrial.gov registration number: NCT03627182) and insulin (cris.nih. go.kr registration number: KCT0002852), a comparison of changes in $\mathrm{HbAlc}$ between lobeglitazone 0.25 and $0.5 \mathrm{mg}$ in patients with T2DM (ClinicalTrial.gov registration number: NCT03770052), and additional pharmacokinetic and drugdrug interaction studies with DPP-4 inhibitors (ClinicalTrial. gov registration number: NCT04431687) and SGLT-2 inhibitors (ClinicalTrial.gov registration number: NCT04334213).

\section{CONCLUSIONS}

Based on the studies summarized in this review, lobeglitazone is a novel TZD with potent efficacy and a favorable safety profile. Lobeglitazone shows similar glycemic efficacy to pioglitazone, with a lower effective dose, owing to its higher affinity to PPAR $\gamma$. Because lobeglitazone is mainly metabolized by the liver, with negligible renal excretion, it is expected that it can be used in patients with renal insufficiency without dose reduction, and it may have a lower risk of bladder cancer than other TZDs. Clinical trials conducted to date also have shown favorable results on safety of lobeglitazone. Additional clinical 
and preclinical studies are expected to provide further evidence of the beneficial effects of lobeglitazone and its mechanism of action.

\section{SUPPLEMENTARY MATERIALS}

Supplementary materials related to this article can be found online at https://doi.org/10.4093/dmj.2020.0272.

\section{CONFLICTS OF INTEREST}

The authors report no potential conflict of interest relevant to this article. Laboratory data analysis and calibration support was provided by Chong Kun Dang Pharmaceutical Corporation, Seoul, Korea.

\section{ORCID}

Jaehyun Bae https://orcid.org/0000-0002-3462-890X

Taegyun Park https://orcid.org/0000-0002-4800-943X

Bong-Soo Cha https://orcid.org/0000-0003-0542-2854

\section{FUNDING}

None

\section{ACKNOWLEDGMENTS}

Under the direction of the authors, medical writing assistance was provided by Kathy Croom and David P. Figgitt PhD, ISMPP $\mathrm{CMPP}^{\mathrm{TM}}$, Content Ed Net.

\section{REFERENCES}

1. Kahn SE. The relative contributions of insulin resistance and beta-cell dysfunction to the pathophysiology of type 2 diabetes. Diabetologia 2003;46:3-19.

2. Lebovitz HE. Thiazolidinediones: the forgotten diabetes medications. Curr Diab Rep 2019;19:151.

3. Lehmann JM, Moore LB, Smith-Oliver TA, Wilkison WO, Willson TM, Kliewer SA. An antidiabetic thiazolidinedione is a high affinity ligand for peroxisome proliferator-activated receptor gamma (PPAR gamma). J Biol Chem 1995;270:12953-6.

4. Kohlroser J, Mathai J, Reichheld J, Banner BF, Bonkovsky HL. Hepatotoxicity due to troglitazone: report of two cases and re- view of adverse events reported to the United States Food and Drug Administration. Am J Gastroenterol 2000;95:272-6.

5. Hanefeld M, Pfutzner A, Forst T, Lubben G. Glycemic control and treatment failure with pioglitazone versus glibenclamide in type 2 diabetes mellitus: a 42-month, open-label, observational, primary care study. Curr Med Res Opin 2006;22:1211-5.

6. Kahn SE, Haffner SM, Heise MA, Herman WH, Holman RR, Jones NP, et al. Glycemic durability of rosiglitazone, metformin, or glyburide monotherapy. N Engl J Med 2006;355:242743.

7. Nissen SE, Wolski K. Effect of rosiglitazone on the risk of myocardial infarction and death from cardiovascular causes. N Engl J Med 2007;356:2457-71.

8. Soccio RE, Chen ER, Lazar MA. Thiazolidinediones and the promise of insulin sensitization in type 2 diabetes. Cell Metab 2014;20:573-91.

9. Lee MA, Tan L, Yang H, Im YG, Im YJ. Structures of PPAR $\gamma$ complexed with lobeglitazone and pioglitazone reveal key determinants for the recognition of antidiabetic drugs. Sci Rep 2017;7:16837.

10. Jang JY, Bae H, Lee YJ, Choi YI, Kim HJ, Park SB, et al. Structural basis for the enhanced anti-diabetic efficacy of lobeglitazone on PPAR $\gamma$. Sci Rep 2018;8:31.

11. Chong Kun Dang Pharmaceutical Corp.: Data on file, 2013. Available from: http://www.ckdpharm.com (cited $2021 \mathrm{Mar}$ 20).

12. Kwon MJ, Lee YJ, Jung HS, Shin HM, Kim TN, Lee SH, et al. The direct effect of lobeglitazone, a new thiazolidinedione, on pancreatic beta cells: a comparison with other thiazolidinediones. Diabetes Res Clin Pract 2019;151:209-23.

13. Kim G, Lee YH, Yun MR, Lee JY, Shin EG, Lee BW, et al. Effects of lobeglitazone, a novel thiazolidinedione, on adipose tissue remodeling and brown and beige adipose tissue development in db/db mice. Int J Obes (Lond) 2018;42:542-51.

14. Rocha RF, Rodrigues T, Menegatti ACO, Bernardes GJL, Terenzi H. The antidiabetic drug lobeglitazone has the potential to inhibit PTP1B activity. Bioorg Chem 2020;100:103927.

15. Sohn JH, Kim JI, Jeon YG, Park J, Kim JB. Effects of three thiazolidinediones on metabolic regulation and cold-induced thermogenesis. Mol Cells 2018;41:900-8.

16. Lee YS, Park JS, Lee DH, Lee DK, Kwon SW, Lee BW, et al. The antidiabetic drug lobeglitazone protects mice from lipogenesisinduced liver injury via mechanistic target of rapamycin complex 1 inhibition. Front Endocrinol (Lausanne) 2018;9:539.

17. Choung S, Joung KH, You BR, Park SK, Kim HJ, Ku BJ. Treat- 
ment with lobeglitazone attenuates hepatic steatosis in diet-induced obese mice. PPAR Res 2018;2018:4292509.

18. Lim S, Lee KS, Lee JE, Park HS, Kim KM, Moon JH, et al. Effect of a new PPAR-gamma agonist, lobeglitazone, on neointimal formation after balloon injury in rats and the development of atherosclerosis. Atherosclerosis 2015;243:107-19.

19. Choi JY, Ryu J, Kim HJ, Song JW, Jeon JH, Lee DH, et al. Therapeutic effects of targeted PPAR $\gamma$ activation on inflamed highrisk plaques assessed by serial optical imaging in vivo. Theranostics 2018;8:45-60.

20. Law RE, Goetze S, Xi XP, Jackson S, Kawano Y, Demer L, et al. Expression and function of PPARgamma in rat and human vascular smooth muscle cells. Circulation 2000;101:1311-8.

21. Jiang C, Ting AT, Seed B. PPAR-gamma agonists inhibit production of monocyte inflammatory cytokines. Nature 1998; 391:82-6.

22. Park S, Ahn JW, Jo Y, Kang HY, Kim HJ, Cheon Y, et al. Labelfree tomographic imaging of lipid droplets in foam cells for machine-learning-assisted therapeutic evaluation of targeted nanodrugs. ACS Nano 2020;14:1856-65.

23. Shin NR, Park SH, Ko JW, Cho YK, Lee IC, Kim JC, et al. Lobeglitazone attenuates airway inflammation and mucus hypersecretion in a murine model of ovalbumin-induced asthma. Front Pharmacol 2018;9:906.

24. Bae KH, Seo JB, Jung YA, Seo HY, Kang SH, Jeon HJ, et al. Lobeglitazone, a novel peroxisome proliferator-activated receptor $\gamma$ agonist, attenuates renal fibrosis caused by unilateral ureteral obstruction in mice. Endocrinol Metab (Seoul) 2017; 32:115-23.

25. Kim KM, Jin HJ, Lee SY, Maeng HJ, Lee GY, Oh TJ, et al. Effects of lobeglitazone, a new thiazolidinedione, on osteoblastogenesis and bone mineral density in mice. Endocrinol Metab (Seoul) 2017;32:389-95.

26. Ali AA, Weinstein RS, Stewart SA, Parfitt AM, Manolagas SC, Jilka RL. Rosiglitazone causes bone loss in mice by suppressing osteoblast differentiation and bone formation. Endocrinology 2005;146:1226-35.

27. Bilezikian JP, Josse RG, Eastell R, Lewiecki EM, Miller CG, Wooddell $\mathrm{M}$, et al. Rosiglitazone decreases bone mineral density and increases bone turnover in postmenopausal women with type 2 diabetes mellitus. J Clin Endocrinol Metab 2013;98: 1519-28.

28. Tseng $\mathrm{CH}$, Tseng FH. Peroxisome proliferator-activated receptor agonists and bladder cancer: lessons from animal studies. J Environ Sci Health C Environ Carcinog Ecotoxicol Rev
2012;30:368-402.

29. Yan H, Xie H, Ying Y, Li J, Wang X, Xu X, et al. Pioglitazone use in patients with diabetes and risk of bladder cancer: a systematic review and meta-analysis. Cancer Manag Res 2018;10: 1627-38.

30. Lee HS, Chang M, Lee JE, Kim W, Hwang IC, Kim DH, et al. Carcinogenicity study of CKD-501, a novel dual peroxisome proliferator-activated receptors $\alpha$ and $\gamma$ agonist, following oral administration to Sprague Dawley rats for 94-101 weeks. Regul Toxicol Pharmacol 2014;69:207-16.

31. Moon KS, Lee JE, Lee HS, Hwang IC, Kim DH, Park HK, et al. CKD-501, a novel selective PPAR $\gamma$ agonist, shows no carcinogenic potential in ICR mice following oral administration for 104 weeks. J Appl Toxicol 2014;34:1271-84.

32. Kim JW, Kim JR, Yi S, Shin KH, Shin HS, Yoon SH, et al. Tolerability and pharmacokinetics of lobeglitazone (CKD-501), a peroxisome proliferator-activated receptor- $\gamma$ agonist: a singleand multiple-dose, double-blind, randomized control study in healthy male Korean subjects. Clin Ther 2011;33:1819-30.

33. Park MK, Kim TE, Kim J, Kim C, Yoon SH, Cho JY, et al. Tolerability and pharmacokinetics of lobeglitazone, a novel peroxisome proliferator-activated receptor- $\gamma$ agonist, after a single oral administration in healthy female subjects. Clin Drug Investig 2014;34:467-74.

34. Kim SY, Jeon JY, Park SJ, Kim MG. Pharmacokinetics of a lobeglitazone/metformin fixed-dose combination tablet (CKD-395 $0.5 / 1000 \mathrm{mg}$ ) versus concomitant administration of single agents and the effect of food on the metabolism of CKD-395 in healthy male subjects. Clin Pharmacol Drug Dev 2019;8:57684.

35. Shin D, Kim TE, Yoon SH, Cho JY, Shin SG, Jang IJ, et al. Assessment of the pharmacokinetics of co-administered metformin and lobeglitazone, a thiazolidinedione antihyperglycemic agent, in healthy subjects. Curr Med Res Opin 2012;28:1213-20.

36. Jang K, Jeon JY, Moon SJ, Kim MG. Evaluation of the pharmacokinetic interaction between lobeglitazone and dapagliflozin at steady state. Clin Ther 2020;42:295-304.

37. Moon SJ, Yu KS, Kim MG. An assessment of pharmacokinetic interaction between lobeglitazone and sitagliptin after multiple oral administrations in healthy men. Clin Ther 2020;42:1047-57.

38. Kim CO, Sil Oh E, Kim C, Park MS. Pharmacokinetic interaction between amlodipine and lobeglitazone, a novel peroxisome proliferator-activated receptor- $\gamma$ agonist, in healthy subjects. Clin Ther 2015;37:1999-2006.

39. Jung JA, Lee SY, Kim TE, Kim JR, Kim C, Huh W, et al. Lack of 
the effect of lobeglitazone, a peroxisome proliferator-activated receptor- $\gamma$ agonist, on the pharmacokinetics and pharmacodynamics of warfarin. Drug Des Devel Ther 2015;9:737-43.

40. Oh ES, Kim CO, Kim KH, Kim YN, Kim C, Lee JI, et al. Effect of ketoconazole on lobeglitazone pharmacokinetics in Korean volunteers. Clin Ther 2014;36:1064-71.

41. Kim SG, Kim DM, Woo JT, Jang HC, Chung CH, Ko KS, et al. Efficacy and safety of lobeglitazone monotherapy in patients with type 2 diabetes mellitus over 24-weeks: a multicenter, randomized, double-blind, parallel-group, placebo controlled trial. PLoS One 2014;9:e92843.

42. Kim SH, Kim SG, Kim DM, Woo JT, Jang HC, Chung CH, et al. Safety and efficacy of lobeglitazone monotherapy in patients with type 2 diabetes mellitus over 52 weeks: an open-label extension study. Diabetes Res Clin Pract 2015;110:e27-30.

43. Jin SM, Park CY, Cho YM, Ku BJ, Ahn CW, Cha BS, et al. Lobeglitazone and pioglitazone as add-ons to metformin for patients with type 2 diabetes: a 24-week, multicentre, randomized, double-blind, parallel-group, active-controlled, phase III clinical trial with a 28-week extension. Diabetes Obes Metab 2015;17:599-602.

44. Kim SG, Kim KJ, Yoon KH, Chun SW, Park KS, Choi KM, et al. Efficacy and safety of lobeglitazone versus sitagliptin as an add-on to metformin in patients with type 2 diabetes with two or more components of metabolic syndrome over 24 weeks. Diabetes Obes Metab 2020;22:1869-73.

45. Lee JY, Cho Y, Lee M, Lee YH, Lee BW, Kang ES, et al. Clinical efficacy of the novel thiazolidinedione lobeglitazone in patients with type 2 diabetes. Diabetes Metab 2018;44:452-5.

46. Lim S, Ku EJ, Lee SY, Lee JH, Lee JE, Kim KM, et al. Therapeutic efficacy and safety of initial triple combination of metformin, sitagliptin, and lobeglitazone in drug-naïve patients with type 2 diabetes: initial triple study. BMJ Open Diabetes Res Care 2020;8:e000807.

47. Aronoff S, Rosenblatt S, Braithwaite S, Egan JW, Mathisen AL, Schneider RL. Pioglitazone hydrochloride monotherapy improves glycemic control in the treatment of patients with type 2 diabetes: a 6-month randomized placebo-controlled dose-response study. The Pioglitazone 001 Study Group. Diabetes Care 2000;23:1605-11.

48. Herz M, Johns D, Reviriego J, Grossman LD, Godin C, Duran $\mathrm{S}$, et al. A randomized, double-blind, placebo-controlled, clinical trial of the effects of pioglitazone on glycemic control and dyslipidemia in oral antihyperglycemic medication-naïve patients with type 2 diabetes mellitus. Clin Ther 2003;25:1074-95.
49. Schernthaner G, Matthews DR, Charbonnel B, Hanefeld M, Brunetti P; Quartet [corrected] Study Group. Efficacy and safety of pioglitazone versus metformin in patients with type 2 diabetes mellitus: a double-blind, randomized trial. J Clin Endocrinol Metab 2004;89:6068-76.

50. Charbonnel BH, Matthews DR, Schernthaner G, Hanefeld M, Brunetti P; QUARTET Study Group. A long-term comparison of pioglitazone and gliclazide in patients with type 2 diabetes mellitus: a randomized, double-blind, parallel-group comparison trial. Diabet Med 2005;22:399-405.

51. Bolli G, Dotta F, Rochotte E, Cohen SE. Efficacy and tolerability of vildagliptin vs. pioglitazone when added to metformin: a 24-week, randomized, double-blind study. Diabetes Obes Metab 2008;10:82-90.

52. Chalasani N, Younossi Z, Lavine JE, Diehl AM, Brunt EM, Cusi K, et al. The diagnosis and management of non-alcoholic fatty liver disease: practice guideline by the American Gastroenterological Association, American Association for the Study of Liver Diseases, and American College of Gastroenterology. Gastroenterology 2012;142:1592-609.

53. Lee YH, Kim JH, Kim SR, Jin HY, Rhee EJ, Cho YM, et al. Lobeglitazone, a novel thiazolidinedione, improves non-alcoholic fatty liver disease in type 2 diabetes: its efficacy and predictive factors related to responsiveness. J Korean Med Sci 2017;32:60-9.

54. Rosenblatt S, Miskin B, Glazer NB, Prince MJ, Robertson KE; Pioglitazone 026 Study Group. The impact of pioglitazone on glycemic control and atherogenic dyslipidemia in patients with type 2 diabetes mellitus. Coron Artery Dis 2001;12:413-23.

55. Goke B; German Pioglitazone Study Group. Improved glycemic control and lipid profile in a randomized study of pioglitazone compared with acarbose in patients with type 2 diabetes mellitus. Treat Endocrinol 2002;1:329-36.

56. Tan M, Johns D, Gonzalez Galvez G, Antunez O, Fabian G, Flores-Lozano F, et al. Effects of pioglitazone and glimepiride on glycemic control and insulin sensitivity in Mexican patients with type 2 diabetes mellitus: a multicenter, randomized, double-blind, parallel-group trial. Clin Ther 2004;26:680-93.

57. Waugh J, Keating GM, Plosker GL, Easthope S, Robinson DM. Pioglitazone: a review of its use in type 2 diabetes mellitus. Drugs 2006;66:85-109.

58. Lim S, Kim KM, Kim SG, Kim DM, Woo JT, Chung CH, et al. Effects of lobeglitazone, a novel thiazolidinedione, on bone mineral density in patients with type 2 diabetes mellitus over 52 weeks. Diabetes Metab J 2017;41:377-85. 